\title{
Passive and Antipassive Voice Ergative Type of Nusantara Language
}

\author{
Invandri Kusuma \\ Magister Ilmu Linguistik \\ University of Diponegoro \\ Semarang, Indonesia \\ E-mail: Invandri.k@gmail.com
}

\begin{abstract}
This study aimed to describe the correlation between voice, which are passive and antipassive, and ergative language in Nusantara. This research is a qualitative research with Agih Method (Descriptive Method) which is to explain facts and with permutation technique support. To obtain data and data sources, the researcher focuses only on the visible variations of the language, from the Nusantara Language on some other written articles or ergative sources, viz orthographic data not from informants. The result of this research is to generate passive diathesis parameter, that is: a) Passive and ergative equally involve at least the property $S$ equal to $P$ rather than $A, b)$ Passive and ergative are different in terms of that ergative typologically involves greater integration of the Agent phrase into the syntax of clauses, c) Passive and ergative are different in terms of marker, and d) Passive sentence in the Nusantara has two types of sequential patterns. They all focus on the patient argument. While the antipassive diathesis construction parameters can be concluded that is, a) antipassives are intransitive, b) the agent can be downgrade to PP for antipassive, and c) indefinite agent is nonreferential in antipassive.
\end{abstract}

Keywords-language typology, ergative, passive, antipassive, Nusantara language.

\section{INTRODUCTION}

Voice of the grammatical alliance of the Nusantara becomes interesting discussion for Arka. In the languages of the Nusantara, the voice studies that have been conducted are, among other things, "Some Intransitive Aspects of Nusantara Languages" (Arka, 2002) "Diathetic Alternatives to some Nusantara Languages" (Arka, 2000) which all collected in the Linguistic Study (Purwo, 2000)

Dixon (1994) explains that there are several ergative languages in Austronesian languages, one of which is the language of the Nusantara. Bugis is one of the most ergative languages (Laskowske, 2011, p. 6). This article aims to examine the relationship between grammatical and diathetic relationships occurring in some languages of the Nusantara, especially passive and antipassive diathesis in languages of ergative type in Nusantara.

The description covers two main points, namely: first, what forms the ergative passive and antipassive voice of the Nusantara Languages are, second, what is the correlation between grammatical relationship and passive and antipassive voice Nusantara Language.

\section{CASE OF USE}

\section{A. Research Purpose}

The present study aims to portray passive and antipassive forms of ergative type of Nusantara language. It also describes the relationship between passive and antipassive voice with an ergative-type language in Nusantara.

\section{B. Background Theory}

\section{1) Ergative-Type Language}

Ergativity in the general sense is the term used to give the pattern seen from the transitivity of the subject, which is from the subject of the intransitive verb being treated the same as the object of transitive verb and has a different pattern to the subject of the transitive verb. Dixon (1972) says that S and O are categorized as subclause, which entail VP, and both of which accept case marker NOM (Legate, 2008) while Comrie says the subject of the intransitive verb is labeled with the $S$ symbol, the subject of the transitive verb is labeled with the symbol A, whereas the transitive verb object is labeled with the P symbol (others use symbols) (Arka \& Jufrizal, 2018)

nominative $\left\{\begin{array}{l}\text { A ergative } \\ \mathrm{s} \\ \text { accusative } \quad \mathrm{O}\end{array}\right\}$ absolutive

For more detailed about the comparison between language having an accusative and an ergative type is as follows (Dixon, 1994, p. 9) 


\section{2) Passive and Antipassive Voice}

Siewierska (Haspelmath, Dryer, Gil, \& Comrie, 2005, p. 343) has formulated the construction of passive voice by displaying the following five features:

a) Construction of passive sentences is different from the construction of other sentences, especially active sentences.

b) Subjects in the construction of passive sentences correspond to oblique objects, or objects in construction of passive sentence become non-mandatory or are not openly expressed.

c) On the passive subject, it is when only one subject will correspond to a direct object or function as subject

d) In pragmatic construction, it is relatively limited to active construction

e) Passive construction also features a special morphological marker of the verb.

Here are some examples that show passive sentences in the ergative language

1. Miiraq gimmi-mik kii-tsip-puq.

child-ABS dog-INSTR bite-pass-3SG

The child is bitten by a dog.

Perlmutter \& Postal (2017, p.7) quoted above examples to show the case of passive voice construction. It is when $\mathrm{O}$ is in ABS which is the same case happens in active construction

According to Polinsky in Haspelmath, Dryer, Gil, \& Comrie (2005) diathesis construction of antipassive sentence is ditransitive construction derived by using a two-place predicate, related to transitive construction which the predicate is the same item. The term antipassive (Silvestein, 1972) was created to show that its construction is similar to passive voice, namely: in a passive construction, suppressed or derived arguments are agent-like arguments while in antipassive, arguments play roles as patients.

\section{Tumg-e yinqey rayegtetew-nin}

friend-ERG son.ABS save-AOR.3SG

his friend he saves*.

The construction of antipassive diathesis is the only argument of a ditransitive verb that can be accessed in its relevant grammatical process. Most of the absolutive ergative languages are the axis for all or most of the grammatical processes, allowing the antipassive subject to occur in absolutive cases.

\section{3) Research Method}

The data of this research were the passive and antipassive voice of ergative type that exists in languages in Nusantara. The data sources of the ergative Nusantara Language were orthographic data from the Balai Bahasa book or other sources, not from the informant. This research is a qualitative research using Agih Method (Descriptive Method). The technique used by the researcher was the Permutation Technique that is the unit or construction (morphological or phraseological) reversed the order in passive sentence structure and antipassive ergative-type of Nusantara Language (Sudaryanto, 2015, p. 15). To analyze the data, it begins describing sentence patterns and phrases of each language. Such a marker system was used to deal with the phenomenon of the election in the Nusantara Language.

\section{DISCUSSION}

\section{A. Passive Voice}

\section{1) Buginese Language}

Buginese Language has a passive construction which involves passive prefix $\mathrm{i}$ - addition to transitive verb.

3. a.Na-tikkeng-i ajé-na buaja-é.

3ERG cath-3ABS leg-3POSS crocodile-DEF

The crocodile caught his leg.

b. I-tikkeng-i ajé-na ku buaja-é. PASS-cath-3ABS leg-3POSS OBL crocodile-DEF His leg was caught by the crocodile.
c. I-tikkeng-i ajé-na.

PASS-tangkap-3ABS kaki-3POSS

His leg was caught. (Laskowske, 2011, p. 49)

If we see the Undergoer Voice (UV) "active" clause in 3)a and passive clauses $3 \mathrm{~b}$ which is the case of the ajé-na "he's feet" is cross-referenced by the absolute enclosure (enclitic) $-i$ on the verb and is an active voice construction. Whereas in the form of passive voice at 3)b, the buaja-e "crocodile" actor is oblique with the characteristics set by the preposition $-k u$ that is no longer a core argument based on SAP. Disappearance can occur at $3 \mathrm{c}$ indicating that a passive sentence is formed from an intransitive sentence so that the object agent of the passive sentence releases

\section{Ir-ita-i panggalung-é ku macang-é.}

PASS-see-3ABS farmer-DEF OBL tiger-DEF

The farmer was seen by the tiger.

Ma-éga béppa i-anré ku acara-é.

STAT-many pastry PASS-eat OBL event-DEF

Many pastries were eaten at the party.

In example 4) above, it suggests that the definite requirement to be a passive sentence construction is part of the definite constraint on all SAPs. Regarding the requirement for oblique passive clause actors, it becomes sure to have a preposition object in general and can be regarded as an indirect consequence of passive voice. The unlimited actor in Buginese language occurs in the UV clause. It is thus understandable that the perspective of passive sentence construction does not permit unlimited actors.

\section{2) Batak Toba Language}

The Batak Toba language is one of the Nusantara languages which has an ergative alliance type (Erlewine, 2017, 
p. 3) and also has two systems that are equally symmetrical to express in passive voice construction. It should be noted that in the 'active' clause or actor-focus clause in this language is controlled by A. The ergative argument will only apply if one considers that the actor's focus is actually an antipassive construct (Cumming \& Wouk, 1987, p. 247)

5. a. Si Poltak may-jaha buku.

PN Poltak AKT-read book

(the*) Poltak reads a book.

\section{b. Buku di-jaha si Poltak.}

book PAS-read PN Poltak

The book is read by (the*) Poltak p. 6)

The example 5 above shows that if a DP is at the beginning of the sentence, then it is the subject. In the above data, it is the first form of canonical active and passive construction contained in the Batak Toba language. Erlewine (2017, p. 7) says that relativization is limited to the subject in Batak Toba as well as in a number of other Austronesian languages. They describe this as an extractive subject restriction.

6. a. Di-jaha si Poltak buku.

PASS-read PN Poltak book

The book is read Poltak.

\section{b. Hu-boto andigan may-uhor buku ho.}

PASS.1TG-tahu ketika AKT-beli buku 2TG

I knew when you bought a book.

Specifically, passive diathesis 6 does not decrease valence, for example, the agent of Poltak continues to be the core argument in non-oblique sentences in a passive construction. Both constructions show the argument of the Poltak to remain close. In more complicated sentences the data $6 \mathrm{~b}$, it is also acceptable.

\section{3) Makassar Language}

The passive voice found in the Napier language has a prefix $n i$ - attached to the verb. The prefix serves to declare the undergoer to the only core argument $(S)$ characterized by ABS inclusions. The derived actor may optionally be expressed in addition preceded by the preposition $r i$ - which follows the verb (Jukes, 2006, p. 244). The contrast between the passive clauses in the transitive sentence is shown below.

7. a. Ay-kanre-a taipa.

AV-eat-1ABS manga

I eat mangoes.

\section{b. Ni-kokko'-a' (ri meong-ku) \\ PASS-bite-1ABS OBL cat-1POSS \\ I was bitten (by my cat).}

The passive sentence in the Makassar language begins with the $n i$ - and PP feature that serves as an optional oblique actor on example 7). The explanation is more accurate for passive analysis as a way of taking emphasis from the Actor.
8. Areng kale-nna iang-ku ma-bassung ni-kana, I Mangayoaberang.

Name himself-3.POSS PROH-1.POSS STV-swell PASSword, name

Personal name, hopefully I'm not mistaken, called I Mangayoaberang.

(Jukes, 2006, p. 113)

In the example data 8 above, it shows that the subject of a passive clause can be focused which explains that there will be no scope. The example shows $\mathrm{S}$ in the focus position, besides the passive form in the data has two types where the passive marker attached to the verbal is simultaneously in front and back.

\section{4) Koastal Konjo Language}

This language is in South Sulawesi region. It has undergoer and ergative features in the form of proclitic which is crossreferenced to the actor as well as the absolute enclitic which is cross-referenced to the undergoer.

\section{Ni-kiring-i-ko sura' (ri bohe-nu). PASS-send-LOC-2TG.ABS letter (OBL grandparent- 2TG.POSS) \\ You were sent a letter (by your grandparent).}

In Koastal Konjo language, a passive sentence construction has a $n i$ - actor and a feature oblique actor in the prepositional phrase, as shown in 9 is taken from Laskowe (Freiberg, 1991, p. 128).

\section{B. Antipassive Voice}

Antipassive on Bugis language is quite interesting because it adds the prefix may- to the transitive verb. The undergoer in syntactically derived function is no longer the core argument of the clause. The constituents of the undergoer structure appear to be oblique and are inserted into a verb (in this case losing its status as an overall actor's argument).

10.a. U-olli-wi

1SG.ERG-call-3ABS

I called him/her.

b. Mang-olli-ka' lao ri aléna.

ANTIP-call-1SG ABS OBL 3SG

I'm calling [to] him/her.

In the antipassive data 10) in the undergoer above, the word aléna "dia" has been derived into oblique marked by the preposition lao $r i$ and is no longer a function of syntactic argument. Meanwhile, the actor has become the core argument referenced by the absolutive-zero enclitic. Decreasing the antipassive undergoer to oblique only works when there is a distance between the verb and the undergoer.

Friberg (Freiberg, 1991, pp. 105, 129) gives the a'- marker as the prefix of the intransitive verb on the antipassive construct Coastal Konjo as Laskowe (Laskowske, 2011, pp. 82-83) has it from the intransitive clause of the transitive verb. 
11.a. A'-ranrang-a. ANTIP-hack1TG.ABS

I hack (something).

b. A'-dongko' oto-a.

ANTIP-ride car-1TG.ABS

I ride in a car.

\section{CONCLUSION}

This article attempts to present pieces of evidence on the Nusantara languages affiliating with ergative-type grammar to show the diathesis mechanism and correlation between the two. All ergative-type Nusantara languages have passive construction, but not all have antipassive constructions, only in Bugis and Koastal Konjo languages (further research is needed).

The following are summarized some parameters of passive voice construction which can be inferred:

a) Passive and ergative equally involve at least the property $S$ equal to $P$ rather than $A$.

b) Passive and ergative differ in terms of that ergative typologically involves greater integration of the Agent phrase into the syntactic clause.

c) Passive and ergative differ in terms of marking. If a passive is a sentence constructed marked sentences, then ergative construction is not.

d) Passive in the Nusantara language has two types of sequential patterns, in the canonical form, the subject is in front of a verb with PASS affix, whereas in other forms, the subject is lowered behind the verb with Prox that accompanies N. All have a focus on the patient Argument.

While the antipassive voice construction parameters can be summarized as follows:

a) Antipassive is intransitive.

b) The agent can be lowered to PP for antipassive.

c) An indefinite agent is non-referential in antipassive.

\section{References}

Arka, I. W. (2000). Alternasi diatesis pada beberapa bahasa nusantara. In B. K. Purwo, Kajian serba linguistik: untuk anton moeliono pereksa bahasa. Jakarta: Unika Atmajaya dan Gunung Mulia.

Arka, I. W. (2002). Voice systems in the Austronesian on nusantara: typology, symetricality and undergoer orientation. MLI-Bali.

Arka, I. W., \& Jufrizal. (2018). Tipologi Linguistik: Konsep dasar dan aplikasinya. Denpasar: Pustaka Larasan.

Cumming, S., \& Wouk, F. (1987). Is There Discourse Ergativity. In Austronesian Languages? Lingua 71.

Dixon, R. M. (1994). Ergativity. Cambridge: Cambridge University Press.
Erlewine, M. Y. (2017). Extraction and licensing in Toba Batak. Extraction and Austronesian-type voice systems. National University of Singapore, Singapore.

Freiberg, B. (1991). Ergativity, focus and verb morphology in several South Sulawesi languages. In R. Harlow, Western Austronesian and contact languages. Auckland: Lingustic Society of New Zealand.

Haspelmath, M., Dryer, M. S., Gil, D., \& Comrie, B. (2005). The world atlas of language structures. Oxford: Oxford University Press.

Jukes, A. (2006). Makassarese. Department of Linguistics and Applied Linguistics (Unpublished Dissertation). University of Melbourne, Melbourne.

Laskowske, D. C. (2011). Voice in Bugis: An Rrg perspective. Bachelor of Arts. Taylor University, Selangor.

Legate, J. A. (2008). Dyrbal Ergativity. LSA Annual Meeting.

Perlmutter, M. D., \& Postal, P. (2014). Toward a universal characterization of passive. Annual Meeting.

Purwo, B. K. (2000). Kajian serba linguistik: untuk Anton Moeliono pereksa bahasa. Jakarta: Unika Atmajaya dan Gunung Mulia.

Silvestein, M. (1972). Chinook jargon: Language contact and the problem of multi-level generative system, II. Linguistic Society of America.

Sudaryanto. (2015). Metode dan aneka teknik analisis bahasa. Yogyakarta: Sanata Dharma University. 